\title{
BIOPSYCHOSOCIAL FACTORS ASSOCIATED WITH MENTAL RETARDATION IN CHILDREN AGED 6-17 YEARS IN TULUNGAGUNG DISTRICT, EAST JAVA
}

\author{
Yani Ikawati1,2), Yulia Lanti Retno Dewi3), Rita Benya Adriani4) \\ 1)Midwifery Academy PGRI Kediri, East Java \\ 2)Masters Program in Public Health, Sebelas Maret University \\ 3)Department of Nutrition, Faculty of Medicine, Sebelas Maret University \\ 4) School of Health Polytechnics Surakarta
}

\begin{abstract}
Background: According to WHO, $15 \%$ of the world population, or 785 million people, suffer mental or physical disorders. Mental retardation is a serious problem socially and medically. Mental retardation affects child development in various forms: physical, self-care, communication, social, emotional, and mental. The objective of this study was to determine biopsychosocial factors associated with mental retardation in children aged 617 years.

Subjects and Method: This study was observational analytic with case control design. It was conducted at Kauman and Tulungangung community health centers in Tulungangung District, East Java, from April to May, 2017. A sample of 100 parents of children aged 6 to 17 years old were selected for this study by fixed disease sampling. This sample consisted of 25 parents of children with mental retardation and 75 parents of children without mental retardation. Children with mental retardation were identified and sampled at a disability special school in Tulungagung, East Java. The dependent variable was mental retardation. The independent variables were prenatal history, perinatal history, maternal stress during pregnancy, maternal education, and family income. The data were collected by a pre-tested questionnaire. Maternal stress was measured by Holmes and Rahe stress scale. The data was analyzed by path analysis.

Results: Mental retardationjn was directly associated with prenatal history $(\mathrm{b}=1.17 ; 95 \% \mathrm{CI}=0.65$ to $2.27 ; \mathrm{p}=0.038)$, perinatal history $(\mathrm{b}=1.41 ; 95 \% \mathrm{CI}=$ 0.87 to $2.73 ; \mathrm{p}=0.037)$, and maternal stress during pregnancy $(\mathrm{b}=1.84 ; 95 \%$ $\mathrm{CI}=0.59$ to $3.09 ; \mathrm{p}=0.004)$. Prenatal history was associated with maternal education $(b=-1.16 ; 95 \% \mathrm{CI}=-2.17$ to $-0.15 ; \mathrm{p}=0.025)$ and maternal stress during pregnancy $(b=1.48 ; 95 \% \mathrm{CI}=0.43$ to $2.54 ; \mathrm{p}=0.006)$. maternal stress during pregnancy was associated with maternal education $(\mathrm{b}=-1.65 ; 95 \% \mathrm{CI}=$ 2.62 to $-0.69 ; \mathrm{p}=0.001)$ and family income $(\mathrm{b}=-1.35 ; 95 \% \mathrm{CI}=2.29$ to -0.41 ; $\mathrm{p}=0.005)$. Family income was associated with maternal education $(\mathrm{b}=1.70$; 95\% CI= 0.82 to $2.57 ; \mathrm{p}<0.001$ ).
\end{abstract}

Conclusion: Mental retardation is directly associated with prenatal history, perinatal history, and maternal stress during pregnancy.

Keywords: mental retardation, biopsychosocial factors, children

Correspondence: Yani Ikawati. Masters Program in Public Health, Sebelas Maret University, Jl. Ir. Sutami 36 A, Surakarta, Central Java.

Email: yaniikawati@gmail.com. Mobile: +6285655730050. 